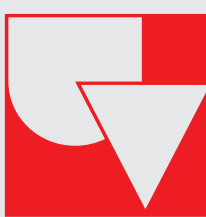

Universidad del Valle

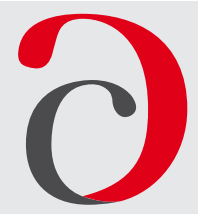

Cuadernos de Administración
Journal of Management

Print ISSN: 0120-4645 / E-ISSN: 2256-5078 / Short name: cuad.adm.

Pages: e1111507 / Vol: 37 / Issue: 70 / May - Aug. 2021

Special issue on Circular Economy

Faculty of Administration Sciences / Universidad del Valle / Cali - Colombia

\title{
Issue 70 - Introduction of articles
}

\author{
Número 70 - Presentación de artículos
}

\section{* Emmanuel Raufflet $\mathbb{D}$}

Professor, HEC Montreal. Guest Editor Circular Economy special issue Cuadernos de Administración e-mail: emmanuel.raufflet@hec.ca

\begin{tabular}{r}
\hline Introduction of articles \\
Submitted: 22/07/2021 \\
Reviewed: $23 / 07 / 2021$ \\
Accepted: $30 / 07 / 2021$ \\
Published: $10 / 08 / 2021$ \\
Thematic lines: Administration and Organizations \\
JEL classification: M14 M21 \\
https://doi.org/10.25100/cdea.v37i70.11507
\end{tabular}

The 70th issue of the Journal Cuadernos de Administración in its 45th anniversary is a special issue on the Circular Economy. The guest editors called for and reviewed papers and made an initial manuscript selection, defined arbitrators and assigned them papers, reviewed the arbitrators' first-round opinion, forwarding their comments to the referees, and reviewed second-round opinions, and forwarded their comments to the authors for a final version and selecting the articles to be published in this special issue. This rigorous process gave us the six papers that we shall introduce below, not without first thanking all the authors from different countries who sent us their manuscripts and thanking the international and Colombian referees who undertook the academic task of making the assessments.

The first article is entitled" Value creation under circular economy practices in the production of viche," and it is a review of scientific literature wherein the authors propose the concept of the circular economy for the agri-food sector in search for increased efficiency in the use of resources by companies with closed production cycles. The authors set out to find practices oriented to creating economic and environmental value for the production of viche in the Colombian Pacific.

"Colombian public policy strategies: transition to a circular economy" is the title of this issue's second paper, which seeks to identify Colombian public policy strategies in the process of transitioning to a circular economy. It is a documentary analysis-coupled descriptive research, which analyzed the Colombian entities linked to this type of public policies, and found, among other things, the need for further articulation in their implementation for better effectiveness in different dimensions.

The third paper hereof is "Circular economy business model: COANIQUEM solidarity store case," wherein the authors start from a concern about waste and cooperation to achieve sustainable development and intend to understand stakeholders' social behavior in a solidarity shop. This is an exploratory case study under qualitative methods in the Chilean COANIQUEM 
solidarity store. Its contribution is to become a study of circular economy strategies at the level of non-governmental organizations.

"The Circular Economy of PET bottles in Colombia" is the title of the fourth article in this issue. Therein, the authors propose a characterization of the Circular Economy strategy for PET (Polyethylene Terephthalate) bottles in Colombia. The work is carried out under a descriptive methodology coupled with content analysis and in-depth interviews.

The fifth article to this issue is entitled "Conceptual contributions of the social and solidarity economy to the Circular Economy." Its author makes a reflection based on an analytical perspective and a review of the foundations of the Social and Solidarity Economy ("SSE") with the Circular Economy ("CE"), finding some complementary aspects.
Finally, the "Circular economy and reduction of consumption from the decolonial approach" is the last paper in this issue, wherein the authors reflect from the decolonial perspective, proposing an alternative to the circular economy. The authors made a conceptual review of articles published between 1990 and 2020 for a methodology and present the co-occurrence relationships and the visualization of semantic communities.

The content of each article is its authors' responsibility; our purpose at Cuadernos de Administración is to disseminate these research results or authors' reflections after a rigorous assessment process. We hope that the articles published in the special Circular Economy issue serve our readers' academic works and research processes in a field of knowledge that, as can be seen, is in the builds and of particular interest nowadays.

How to cite this paper?

Raufflet, E. (2021). Issue 70 - Introduction of articles. Cuadernos de Administración, 37(70), 1111507.

https://doi.org/10.25100/cdea.v37i70.11507

Cuadernos de Administraciónjournal by Universidad del Valle is under licence Creative Commons Reconocimiento-

NoComercial-SinObrasDerivadas 4.0. Based in http://cuadernosdeadministracion.univalle.edu.co/ 